\title{
Air Bleeding Strategies to Increase the Efficiency of Proton Exchange Membrane Fuel Cell Stationary Applications Fuelled with CO ppm-levels
}

\author{
S. Delgado, T. Lagarteira and A. Mendes* \\ Laboratory for Process Engineering, Environmental, Biotechnology and Energy (LEPABE), Faculty of \\ Engineering of University of Porto, Rua Dr. Roberto Frias s/n, 4200-465 Porto, Portugal \\ "E-mail: mendes@fe.up.pt;
}

Received: 12 August 2019 / Accepted: 28 September 2019 / Published: 30 November 2019

\begin{abstract}
The use of proton exchange membrane fuel cells (PEMFCs) as efficient electric generators for residential and tertiary sectors to replace conventional internal combustion engines greatly depends on the recent advances in purification technologies. Preferential oxidation and pressure swing adsorption offer reformate hydrogen streams with $\mathrm{CO}$ concentrations down to fractional ppm level. However, even small traces of $\mathrm{CO}$ cause reversible and irreversible performance losses of the PEMFC stack due to poisoning of the anode Pt catalyst. This work reports the performance loss upon $\mathrm{H}_{2}$ contamination down to the ppm level and the efficiency gains after applying internal and external air bleeding to the anode of the fuel cell. This work studies both air bleeding strategies under operating conditions typical for stationary applications. By adding solely $1 \%$ of air bleed to a $10 \mathrm{ppm} \mathrm{CO}$ contaminated hydrogen stream, it is possible to recover the full performance without compromising the steadiness of the cell. Moreover, a performance loss of $<1 \%$ - DOE target value for reformate streams - can be met using Pt-Ru based anode catalysts allied to a minimal air bleed concentration. Long-term experiments, $c a$. $80 \mathrm{~h}$, were performed to assess the stability of the fuel cells fed with contaminated hydrogen and compare the longterm impacts of both internal and external air bleeding.
\end{abstract}

Keywords: Proton exchange membrane fuel cell; Membrane electrodes assembly; CO poisoning; Air bleeding.

\section{INTRODUCTION}

Low-temperature proton exchange membrane fuel cells (PEMFCs) are considered an attractive candidate to power small stationary units including off-grid energy, backup power systems and combined heat and power (CHP) for industry and buildings. CHP systems based on fuel cells are expected to replace natural gas heaters for domestic cogeneration, because of their higher fuel efficiency, modularity, and environmentally friendly operation [1]. However, some challenges still hinder the 
widespread commercialization of the technology. The core component of the fuel cell, the membraneelectrodes assembly (MEA), plays a crucial role on the overall cost of fuel stacks due to the need of highly active and durable catalysts and electrodes. In parallel to the high cost of the precious-metal catalysts, the small world-wide production of highly pure hydrogen is a major drawback [2].

Systems for stationary applications usually adopt a fuel processor to produce hydrogen from fossil (natural gas, LPG) or renewable (bio-ethanol, bio-gas) fuels [3]. The reforming of hydrocarbons followed by water-gas shift and purification is the most common production route of hydrogen. Nonetheless, this production route still delivering contaminants $\left(\mathrm{CO}_{2}, \mathrm{H}_{2} \mathrm{~S}\right.$ and mainly $\left.\mathrm{CO}\right)$ in the hydrogen stream that poison platinum catalyst activity and durability [4,5]. Therefore, ISO 14687-3 details hydrogen quality requirements for PEM fuel cells for stationary applications. In particular, it defines three categories: two with $\mathrm{H}_{2} \geq 50 \%$ and $\mathrm{CO} \leq 10 \mathrm{ppm}$, and one with $\mathrm{H}_{2} \geq 99.9 \%$ and $\mathrm{CO} \leq 0.2$ ppm. Hydrogen produced by conventional fuel processors can fulfil the requirements of the first two categories. Japan appears as the world leader on micro-combined heat and power systems based on fuel cells (m-CHP-PEMFC) for buildings with over 140000 units sold; likewise, Europe is expected to promote the exponential growing of m-CHP-PEMFC [6,7]. The chemisorption of $\mathrm{CO}$ on Pt catalyst particles surface reduces the number of active sites for $\mathrm{H}_{2}$ electro-oxidation [8,9] and hence the fuel cell power output and its useful life. The performance of the fuel cell anode is then highly sensitive to small traces of $\mathrm{CO}$ (down to fractional ppm level) and dependent on operating conditions such as temperature, the exposure time to $\mathrm{CO}$, pressure, current density, relative humidity and fuel stoichiometry [10]. Carbon dioxide has a minimal affinity for the Pt catalyst and therefore does not affect the performance of the cell at low current densities $\left(<300 \mathrm{~mA} \mathrm{~cm}^{-2}\right)$, behaving as an inert species [11].

In the last two decades, several works have been published focusing on the mitigation of $\mathrm{CO}$ poisoning in PEM fuel cells [10,12-14]. The most conventional approach is to use CO-tolerant catalysts at the anode, normally obtained by combining Pt with other metals. Pt-Ru alloy is typically used as COtolerant catalyst albeit some impact on the fuel cell durability due to Ru dissolution and migration to the cathode $[15,16]$. The $\mathrm{CO}$ tolerance evidenced by PtRu catalysts is mainly attributed to two mechanisms, the electronic tuning of $\mathrm{Pt}$ d-band structure (ligand effect) and/or the acceleration of $\mathrm{CO}$ oxidation to $\mathrm{CO}_{2}$ by providing oxygen species to $\mathrm{CO}_{\mathrm{ad}}$ on $\mathrm{Pt}$ surfaces [17]. The ligand effect consists in the modification of Pt electronic structure that either weakens the $\mathrm{Pt}-\mathrm{CO}$ bond thus promoting $\mathrm{CO}$ oxidation by nearby $\mathrm{OH}$ groups; or improves $\mathrm{Pt}-\mathrm{H}_{2} \mathrm{O}$ activation that leads to direct oxidation of $\mathrm{CO}$ on the $\mathrm{Pt}$ sites [18].

Another approach to inhibit $\mathrm{CO}$ poisoning is to introduce trace concentrations of oxygen in the anode. Oxygen can be supplied to the anode by: i) internal oxygen/air bleeding from the cathode through the membrane; ii) external oxygen/air bleeding; iii) introduction of $\mathrm{H}_{2} \mathrm{O}_{2}$ in the anode bubbler [10]. Oxygen permeation through the membrane is commonly described in terms of sorption-diffusion mechanisms [19]; specifically, during PEMFC operation oxygen sorbs into the membrane and diffuses from the cathode to the anode side preferably through its hydrated pathways. The membrane permeability to oxygen is proportional to the product of Fick's diffusion coefficient and solubility coefficient [20],[21]. The membrane permeability to oxygen increases with the operating temperature and with the membrane humidification [22-25]. On the other hand, oxygen permeation increases with the partial pressure difference between the two sides of the membrane but decreases with increasing 
membrane thickness [26]. The permeated oxygen is partly responsible for the oxidation of $\mathrm{CO}$ to $\mathrm{CO}_{2}$ in the anode catalyst particles surface through heterogeneous catalysis described by the LangmuirHinshelwood mechanism [27]. Yet, some negative aspects may arise from the presence of excessive $\mathrm{O}_{2}$ at the anode such as higher anode overpotential caused by water production from the hydrogen oxidation, catalyst sintering due to the highly exothermic hydrogen oxidation, and membrane degradation from the side-production of $\mathrm{H}_{2} \mathrm{O}_{2}$ [16]. Therefore, air (oxygen) bleeding must be tuned depending on the $\mathrm{CO}$ contamination levels [28].

In this work, the impacts of two different techniques for the mitigation of $\mathrm{CO}$ poisoning, internal and external air bleeding, are assessed. For both techniques, oxygen traces at the anode were tuned to determine the minimum amount able to fully recover the efficiency drop caused by $\mathrm{CO}$ poisoning. Midterm operation under $\mathrm{CO}$ contamination was compared for both techniques to assess the degradation through potential decay. To the best of the authors' knowledge, these techniques are compared for the first time under PEMFC operating conditions suitable for stationary applications, such as m-CHPPEMFC.

\section{EXPERIMENTAL}

The electrochemical measurements were carried out in a $25 \mathrm{~cm}^{2}$ fuel cell manufactured by Pragma Industries. The graphite flow fields used in both the anode and cathode were single channel type. The cell compression was set to $c a$. $2 \mathrm{MPa}$, thus guaranteeing the electrical contact between the gas diffusion electrodes (GDE) and the bipolar plates.

MEA\#1 was made of a Nafion 212 membrane (N212, $51 \mu \mathrm{m}$ of thickness) sandwiched by two GDEs, all purchased to Quintech. The anode catalyst layer contained $0.5 \mathrm{mg} \mathrm{cm}^{-2}$ of PtRu and the cathode catalyst layer had $0.5 \mathrm{mg} \mathrm{cm}{ }^{-2}$ of Pt. The GDEs were hot-pressed to the membrane at $120{ }^{\circ} \mathrm{C}$ and 17 bar for 5 minutes. The French Alternative Energies and Atomic Energy Commission (CEA) provided MEA\#2 that employs a Nafion reinforced-stabilized HP membrane (NRHP) with $22 \mu \mathrm{m}$ of thickness. The catalyst layers contained $0.585 \mathrm{mg} \mathrm{cm}^{-2}$ of PtRu (66 wt.\% of Pt) in the anode and PtCo alloy with $0.468 \mathrm{mg} \mathrm{cm}^{-2}$ of Pt in the cathode. The gas diffusion layers of both MEAs (Sigracet $28 \mathrm{BC}$, SGL Carbon) were $220 \mu \mathrm{m}$ thick.

The mass flow rates of the reactants, humidification and temperatures of the lines were controlled with a test station. The anode was fed with either high purity $\mathrm{H}_{2}(99.999 \%)$, mixtures of $\mathrm{CO} / \mathrm{H}_{2}$ or synthetic air whilst the cathode was fed with synthetic air. $\mathrm{CO}$ was supplied from a cylinder containing a mixture of $\mathrm{H}_{2}$ balanced with $100 \mathrm{ppm}$ of $\mathrm{CO}$ (Linde). Anode and cathode were humidified by bubbling the feed gases into ultra-pure water; the relative humidity was set to $50 \%$ for both the anode and cathode. The stoichiometries of the reactants were set to $1.5 / 2$ for the anode and cathode, respectively. Subsequently, the consumed reactant flow rates were calculated using Faraday's equation, assuming a coulombic efficiency of $100 \%$.

An electrochemical workstation (Zahner IM6eX) coupled with a PP-240 power potentiostat was used to perform the electrochemical measurements. The MEAs were subjected to break-in at $500 \mathrm{~mA}$ $\mathrm{cm}^{-2}$. The conditions for the break-in and experiments of interest are described in Table 1. The break-in 
step (conditions of Run\# 1) was considered completed when the cell potential variation was less than 5 $\mathrm{mV} \mathrm{h}^{-1}$ at $500 \mathrm{~mA} \mathrm{~cm}^{-2}$.

After achieving steady-state performance, a polarization curve was recorded in galvanostatic mode. The cell potential was recorded (Run\# 2) as a function of the current density with a dwell time of 3 minutes. Chronopotentiometries were performed at $500 \mathrm{~mA} \mathrm{~cm}^{-2}$ following the conditions of Run \#2Run \#10 to evaluate the magnitude of performance loss due to $\mathrm{CO}$ exposure and the performance gains after implementing each bleeding technique.

Electrochemical impedance spectroscopy (EIS) was performed in galvanostatic mode at $500 \mathrm{~mA}$ $\mathrm{cm}^{-2}$, with a perturbation amplitude of $40 \mathrm{~mA} \mathrm{~cm}^{-2}$ between $10 \mathrm{kHz}$ and $100 \mathrm{mHz}$.

Figure 1 depicts the equivalent circuit of elements used to fit the electrochemical impedance spectra. The equivalent circuit chosen comprises two simple Randle's circuits, each with a constant phase element $\left(Q_{\mathrm{a} / \mathrm{c}}\right)$ and a resistor $\left(R_{\mathrm{a} / \mathrm{c}}\right)$ in parallel, along with a resistor connected in series $\left(R_{\mathrm{m}}\right)$ [29]. $R_{\mathrm{m}}$ accounts mostly for the resistance associated to protonic conduction through the membrane, $R_{\mathrm{a}}$ and $R_{\mathrm{c}}$ are the charge transfer resistances associated to anode and cathode, respectively. EIS low frequency data, related to mass transfer overpotential, was not included in the fittings since it was not preponderant for this study.

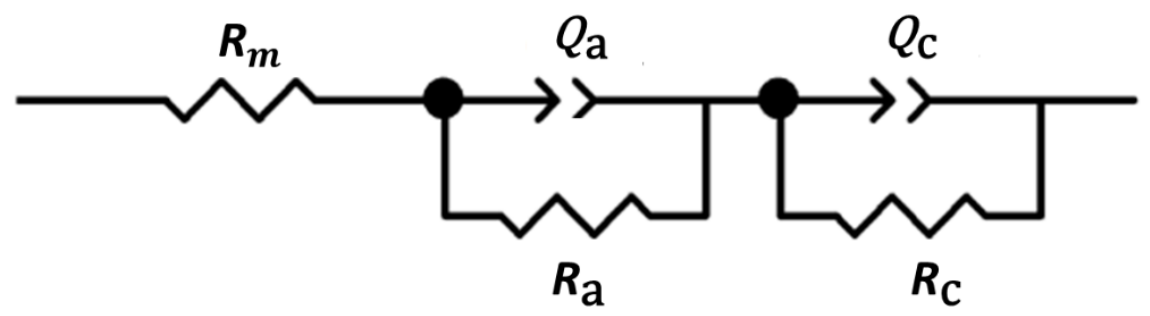

Figure 1. Schematic representation of the equivalent circuit for the PEMFC.

In-situ cyclic voltammetry (CV) was performed to both anode and cathode of the MEAs to estimate the electrochemical surface area (ECSA) at the beginning and end of experiments. The working electrode was purged with $\mathrm{N}_{2}$ to remove any adsorbed $\mathrm{O}_{2}$, and the counter electrode was fed with $\mathrm{H}_{2}$, maintaining the stoichiometry and flow rates calculated for $100 \mathrm{~mA} \mathrm{~cm}$-2 between $\mathrm{H}_{2} / \mathrm{O}_{2}$. The relative humidity was set to $50 \%$, the back pressure was set to 1.5 bar for both electrodes, the scan rate was set to $50 \mathrm{mV} \mathrm{s}^{-1}$ and the cell temperature was kept at $70^{\circ} \mathrm{C}$.

Table 1. Performed tests and corresponding operating conditions.

\begin{tabular}{|c|c|c|c|c|c|c|c|}
\hline$\#$ & MEA\# & $\boldsymbol{p} \mathbf{H}_{2}$ & $\boldsymbol{p}$ Air & RH $\mathbf{H}_{2}$ & RH Air & Fuel & Temperature \\
\hline 1 - Break-in & $1 / 2$ & 1.5 & 1.5 & $80 \%$ & $80 \%$ & Pure $\mathrm{H}_{2}$ & $80^{\circ} \mathrm{C}$ \\
\hline 2 - Reference & $1 / 2$ & 1.2 & 1.2 & $50 \%$ & $50 \%$ & ${\text { Pure } \mathrm{H}_{2}}$ & $70^{\circ} \mathrm{C}$ \\
\hline
\end{tabular}




\begin{tabular}{|c|c|c|c|c|c|c|c|}
\hline 3 & $1 / 2$ & 1.2 & 1.2 & $50 \%$ & $50 \%$ & $\mathrm{H}_{2}+10 \mathrm{ppm} \mathrm{CO}$ \\
\hline 4 & $1 / 2$ & 1.1 & 1.2 & $50 \%$ & $50 \%$ & $\mathrm{H}_{2}+10 \mathrm{ppm} \mathrm{CO}$ \\
\hline 5 & $1 / 2$ & 1.1 & 1.3 & $50 \%$ & $50 \%$ & $\mathrm{H}_{2}+10 \mathrm{ppm} \mathrm{CO}$ \\
\hline 6 & 2 & 1.1 & 1.3 & $50 \%$ & $50 \%$ & $\mathrm{H}_{2}+20 \mathrm{ppm} \mathrm{CO}$ \\
\hline 7 & 2 & 1.1 & 1.3 & $50 \%$ & $50 \%$ & $\mathrm{H}_{2}+30 \mathrm{ppm} \mathrm{CO}$ \\
\hline 8 & 1 & 1.2 & 1.2 & $50 \%$ & $50 \%$ & $\mathrm{H}_{2}+10 \mathrm{ppm} \mathrm{CO}+0.5 \% \mathrm{Air}$ & $70{ }^{\circ} \mathrm{C}$ \\
\hline 9 & $1 / 2$ & 1.2 & 1.2 & $50 \%$ & $50 \%$ & $\mathrm{H}_{2}+10 \mathrm{ppm} \mathrm{CO}+1 \% \mathrm{Air}$ & $70{ }^{\circ} \mathrm{C}$ \\
\hline
\end{tabular}

\section{RESULTS AND DISCUSSION}

\subsection{Electrochemical performance with pure $\mathrm{H}_{2}$}

The polarization curves (Figure 2a) and EIS spectra at $500 \mathrm{~mA} \mathrm{~cm}^{-2}$ (Figure $2 \mathrm{~b}$ ) of MEA\#1 and MEA\#2 were obtained for Reference conditions -Table 1. MEA\#2 outperformed MEA\#1 at current densities higher than $300 \mathrm{~mA} \cdot \mathrm{cm}^{-2}$. The greater thickness of membrane $\mathrm{N} 212$, inserted in MEA\#1, compared with membrane NRHP, inserted in MEA\#2, makes its ohmic overpotential higher, limiting the protonic conduction and decreasing the power output [30]. Nafion HP is a sandwich type membrane, similar to its predecessor Nafion XL ( ca. $28 \mu \mathrm{m})$, comprising an inner layer of PTFE-rich reinforcing mesh for mechanical stability, coated with two ultra-thin layers of Nafion in each side (ca. $7 \mu \mathrm{m}$ thick each). This membrane provides high proton conductivity with better chemical/mechanical durability compared to the benchmark counterparts (e.g. Nafion 212 or Nafion 115) [31-33]. Nonetheless, the activation overpotential region $\left(<100 \mathrm{~mA} \cdot \mathrm{cm}^{-2}\right)$ of MEA\#2 is higher comparing to MEA\#1, thanks to the higher Pt loading of the latter. Nevertheless, ohmic overpotentials are smaller for MEA\#2 (Figure 2a). From the EIS spectra (Figure 2b), the difference in the ohmic resistances of MEA\#2 and MEA\#1 $107.4 \mathrm{~m} \Omega \mathrm{cm}^{2}$ vs $221.4 \mathrm{~m} \Omega \mathrm{cm}^{2}$, respectively - was assigned to the membranes thickness where MEA\#2 is equipped with a membrane $c a .50 \%$ thinner $(22 \mu \mathrm{m})$ than MEA\#1 $(51 \mu \mathrm{m})$; these results are in line with previous studies [34,35]. Ohmic losses tend to increase linearly with membrane thickness [36]. Additionally, the lower mass transport overpotential of MEA\#2 suggests the existence of more gas and liquid diffusion-pathways in the cathode catalyst layer. 

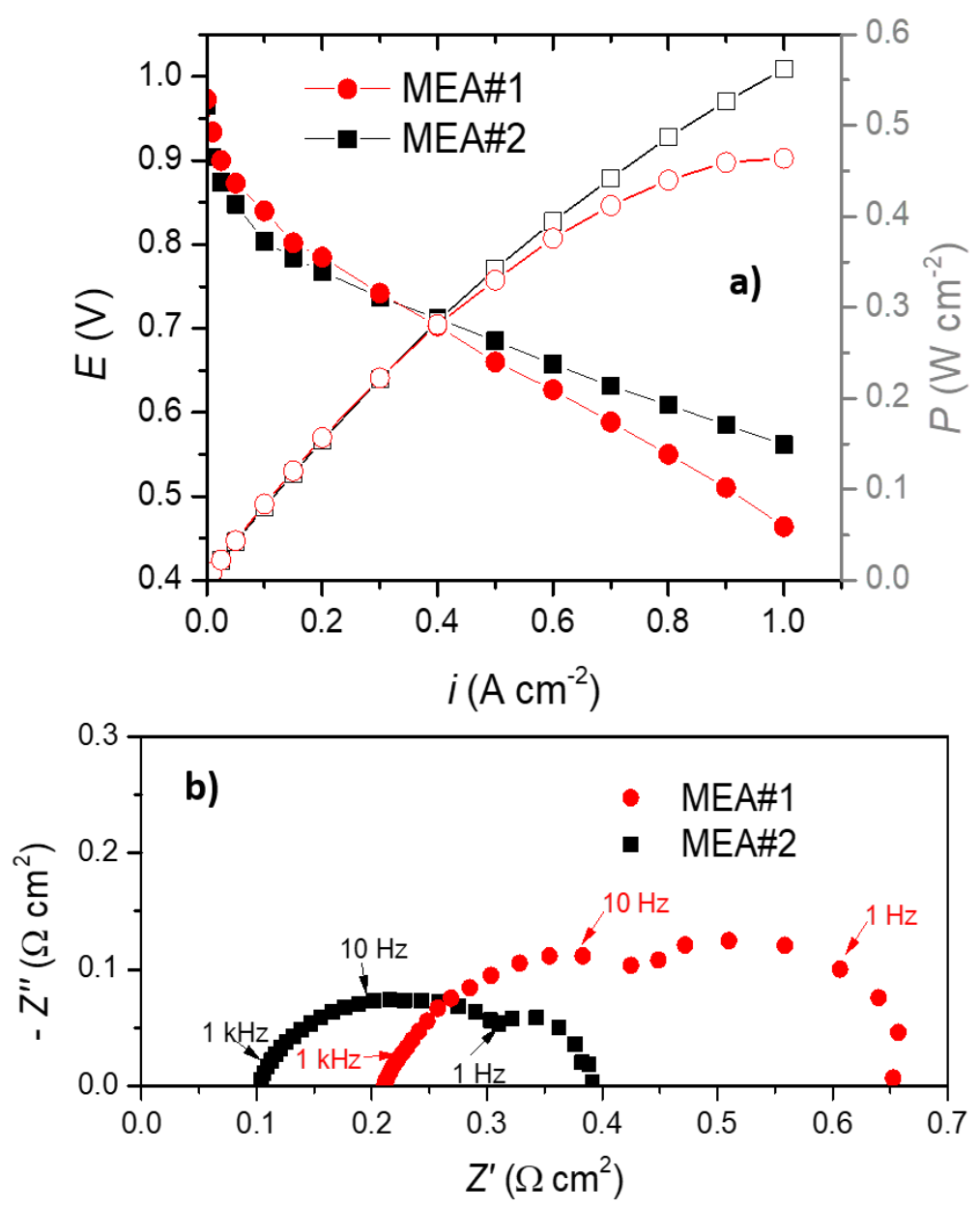

Figure 2. Comparison between the two tested MEAs under the conditions of Run\#2 (from Table 1.) by a) a polarization curve; b) EIS at $500 \mathrm{~mA} \cdot \mathrm{cm}^{-2}$.

Hereafter both MEA\#1 and MEA\#2 will assess the defined strategies to mitigate CO contamination - internal and air bleeding - under the operating conditions shown in Table 1. Runs \#3 $\# 13$.

\subsection{Internal air bleeding}

Internal air bleeding was controlled by setting a pressure difference between the two electrodes. The solubility of oxygen in water, which controls the oxygen transport to the anode, is related to its partial pressure. Therefore, the cathode side pressure must be higher to promote oxygen permeation through the membrane [26]. Error! Reference source not found.a shows chronopotentiometries of MEA\#1, at $500 \mathrm{~mA} \mathrm{~cm}^{-2}$, for pure hydrogen feed (Run \#2) and for hydrogen with $10 \mathrm{ppm}$ of CO feed (Runs \#3, \#4 and \#5). With the introduction of $\mathrm{CO}$ at the anode, a linear loss of cell potential was observed until reaching a new steady-state. The effect of the internal air bleeding was not evident up to 0.1 bar of pressure difference. At 0.2 bar of cathode over-pressure, the steady-state cell potential increased $c a .20 \mathrm{mV}$, denoting a partial recovery of catalyst poisoning by $\mathrm{CO}, \mathrm{ca} .51 \%$.

The impedance spectra obtained at $500 \mathrm{~mA} \mathrm{~cm}^{-2}$, were fitted to an EC shown in 
Figure 1 to better diagnose the effect of the $\mathrm{CO}$ poisoning mitigation strategies. From the EIS spectra (Figure 3b), in the high-frequency region the anodic charge transfer resistance increased significantly when CO was fed with no internal bleeding $-R_{\mathrm{a}}=67.8 \mathrm{~m} \Omega \mathrm{cm}^{2}$ vs $R_{\mathrm{a}}=120 \mathrm{~m} \Omega \mathrm{cm}^{2}$. When an internal bleeding is employed, $\Delta P=0.2$ bar, the anodic charge transfer resistance decreased significantly, $R_{\mathrm{a}}=82.9 \mathrm{~m} \Omega \mathrm{cm}^{2}$ (Table 2 ).
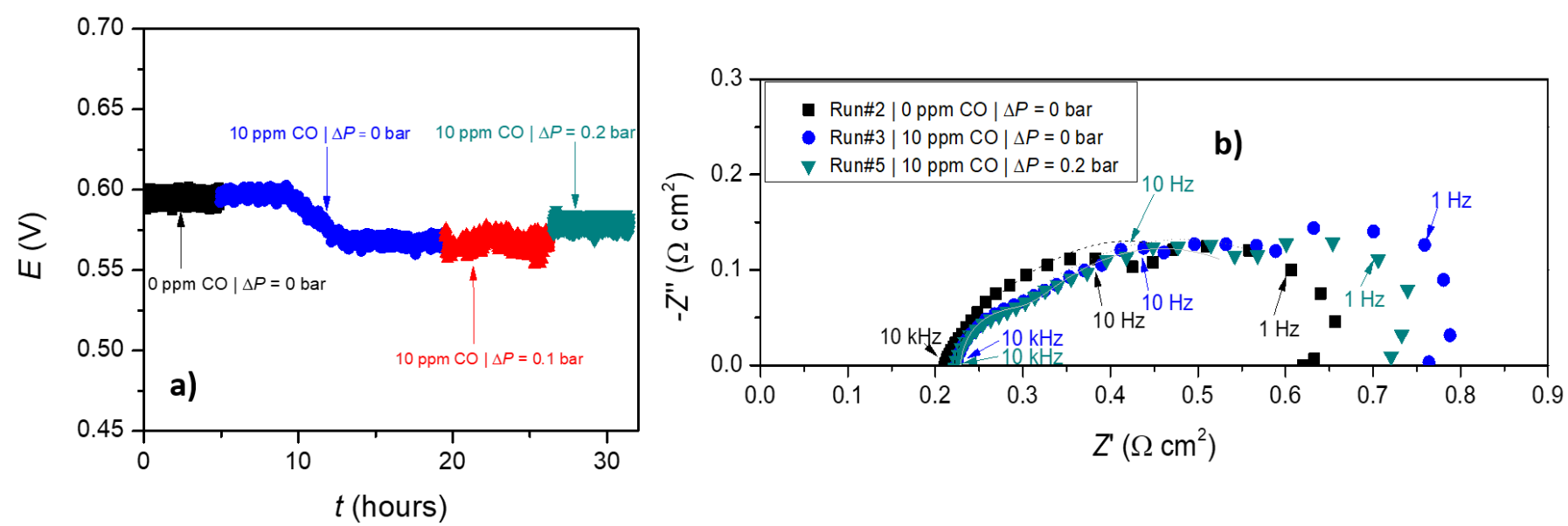

Figure 3. Effect of internal air bleeding on a) chronopotentiometry and b) EIS at $500 \mathrm{~mA} \mathrm{~cm}^{-2}$ of MEA\#1.

Table 2. Summary of fitted values from EIS data using the equivalent circuit shown in Figure 1 for MEA\#1 and\#2; (Frequency range of the EIS fitted data: $2.5 \mathrm{kHz}-10 \mathrm{~Hz}$ ).

\begin{tabular}{|c|c|c|c|c|c|c|}
\hline MEA & $\#$ & $R \mathbf{m} / \mathrm{m} \Omega \mathrm{cm}^{2}$ & $R \mathrm{a} / \mathrm{m} \Omega \mathrm{cm}^{2}$ & $Q_{\mathrm{a}} / \mathrm{F} \mathrm{cm}^{2}$ & $R \mathrm{c} / \mathrm{m} \Omega \mathrm{cm}^{2}$ & $Q_{\mathrm{c}} / \mathrm{F} \mathrm{\textrm {cm } ^ { 2 }}$ \\
\hline \multirow{4}{*}{1} & $2-0$ ppm CO & 221.4 & 67.8 & $639 \mathrm{~m}$ & 293.2 & $789 \mathrm{~m}$ \\
\hline & 3- 10 ppm CO & 243 & 117.7 & $294 \mathrm{~m}$ & 347.5 & $443.8 \mathrm{~m}$ \\
\hline & $5-10 \mathrm{ppm} \mathrm{CO} \mid \Delta P=0.2$ bar & 233.2 & 82.9 & $146.9 \mathrm{~m}$ & 326.5 & $254.9 \mathrm{~m}$ \\
\hline & $\mathbf{1 0}-10 \mathrm{ppm} \mathrm{CO}+1.5 \%$ air bleed & 213.1 & 67.5 & $681.5 \mathrm{~m}$ & 278.3 & $790.5 \mathrm{~m}$ \\
\hline \multirow{4}{*}{2} & $2-0$ ppm CO & 107.4 & 49.5 & 16.1 & 174 & 23.7 \\
\hline & 3 - 10 ppm CO & 125.4 & 237.4 & 11 & 315.8 & 6.3 \\
\hline & 5 - 10 ppm CO $\mid \Delta P=0.2$ bar & 122.5 & 224.3 & 7.9 & 252.5 & 9.4 \\
\hline & $9-10$ ppm CO + 1\% air bleed & 109.4 & 44.6 & 15.6 & 160.7 & 22.4 \\
\hline
\end{tabular}

Runs \#2,\#3,\#4 and \#5 were repeated with MEA\#2. Figure 4a displays the chronopotentiometries of MEA\#2 at $500 \mathrm{~mA} \mathrm{~cm}^{-2}$. After CO contamination, the steady-state cell potential increased with the cathode over-pressure ( $c a .10 \pm 2 \mathrm{mV}$ per 0.1 bar). Therefore, internal air bleeding effect is hardly noticeable in EIS (Figure 4b), since the spectra of Runs \#3 and \#5 almost overlap. Moreover, .the effect 
of internal air bleeding with an over-pressure of 0.2 bar allows a recovery of $25 \%$ of the pristine performance and a reduction of anode charge transfer resistance of $c a .10 \mathrm{~m} \Omega \mathrm{cm}^{2}$, comparing with Run \#3, according to the EIS fitting - Table 2.

Oxygen bleeding on several membranes has been a subject of several studies, which report that CO poisoning mitigation is lower for thicker membranes like Nafion 115 (127 $\mu \mathrm{m})$ [27]; the work of Wang [37] reported higher oxygen bleeding when the cathode over-pressure increases in ultra-thin membranes $(5 \mu \mathrm{m}$ and $25 \mu \mathrm{m})$. These evidences support that performing internal bleeding for $\mathrm{CO}$ poisoning mitigation is more effective if thin membranes are used. By promoting back diffusion of water dissolved oxygen through thin membranes (internal bleeding), more $\mathrm{CO}$ present at the anode can be oxidized to $\mathrm{CO}_{2}$, thus reducing the anode overpotential caused by $\mathrm{CO}$ poisoning. Increments on the cathode total pressure promotes $\mathrm{CO}$ oxidation [37] but only ca. $0.25 \%$ of the crossed oxygen molecules oxidize $\mathrm{CO}$ to $\mathrm{CO}_{2}$ [37]. In the present study, a similar performance gain was achieved for both MEA\#1 and MEA\#2, as seen in Figure 3a and Figure 4b. Nonetheless, no more than $40 \%$ of the initial performance could be re-established; pressure gradients higher than 200 mbar between the electrodes were not employed to avoid high mechanical stress that could lead to form pin-holes in the membrane and consequent gas crossover or internal short-circuits.

There is no agreement whether Nafion-PTFE composite membranes display better gas barrier properties compared with plain Nafion membranes (e.g. Nafion 115, Nafion 117 among others); several works [38-40] report greater permeabilities of Nafion/PTFE composite membranes to oxygen and nitrogen. The PTFE mesh in the composite membrane allows to reduce the overall membrane thickness (from typical ca. $185 \mu \mathrm{m}$-Nafion 117 - to less than $40 \mu \mathrm{m}$ ) while keeping the mechanical stability. These authors observed higher composite membrane permeabilities to gas relatively to thicker non-reinforced membranes [41]. On the other hand, Yu and his co-workers developed a Nafion/PTFE composite with an overall thickness of $20 \pm 5 \mu \mathrm{m}$ and, upon scanning electron microscopy analysis, they confirmed that PTFE pores were completely filled with the Nafion resin. The permeability of the composite membrane to nitrogen was reduced when comparing to non-reinforced Nafion 112, 115 or 117 [39].
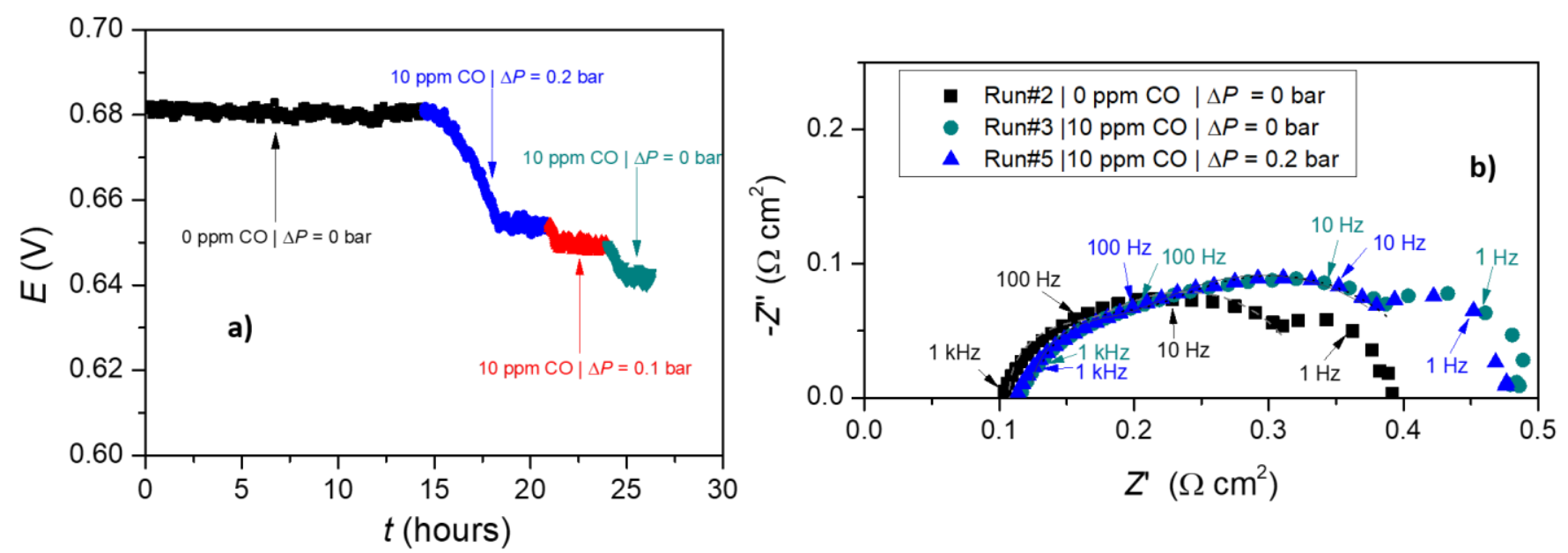

Figure 4. Effect of internal bleeding in MEA\#2 at $500 \mathrm{~mA} \cdot \mathrm{cm}^{-2}$ on a) chronopotentiometry and b) EIS. 
In the present study, the use of a thinner membrane (Nafion HP in MEA\#2) did not provide better internal bleeding-based performance recovery than thicker Nafion 212 membrane (MEA\#1). Nafion HP membranes are reinforced with a backbone that makes them not only mechanically more stable but also less permeable to both hydrogen and oxygen. The lower permeability to oxygen limits internal bleeding and thus $\mathrm{CO}$ mitigation is less effective comparing to non-reinforced membranes of similar thickness.

Higher concentrations of $\mathrm{CO}$ in the fuel stream were also tested together with internal bleeding. The pressure difference between cathode and anode was set to 200 mbar to enable internal air bleeding under different $\mathrm{CO}$ contaminations. Figure 5a shows the chronopotentiometries for four levels of $\mathrm{CO}$ contamination $(0,10,20$ and $30 \mathrm{ppm})$. The efficiency of the cell provided with MEA\#1 at $500 \mathrm{~mA} \mathrm{~cm}^{-2}$ and $80{ }^{\circ} \mathrm{C}$ fell from the initial value of $45.2 \%$ while feeding neat $\mathrm{H}_{2}$ to progressively lower efficiencies, ca. $-0.55 \%$ with each increase of $10 \mathrm{ppm}$ of CO. In this regard, the steady state potential decreased with the $\mathrm{CO}$ concentration, mainly because of increasing anode overpotential.

The impedance spectra (Figure 5b), obtained after each chronopotentiometry, unveils that higher $\mathrm{CO}$ concentrations increase the overall impedance. The differences are clear for frequencies lower than $1 \mathrm{~Hz}$, where gradual increments of $10 \mathrm{ppm}$ in the $\mathrm{CO}$ concentration originate two-fold higher anode charge transfer resistances, i.e., the resistance increases $c a .20 \mathrm{~m} \Omega \mathrm{cm}^{2}$ when $C O$ passes from $10 \mathrm{ppm}$ to $20 \mathrm{ppm}$, and $c a .40 \mathrm{~m} \Omega \mathrm{cm}^{2}$ when passing from $20 \mathrm{ppm}$ and $30 \mathrm{ppm}$ of $\mathrm{CO}$.
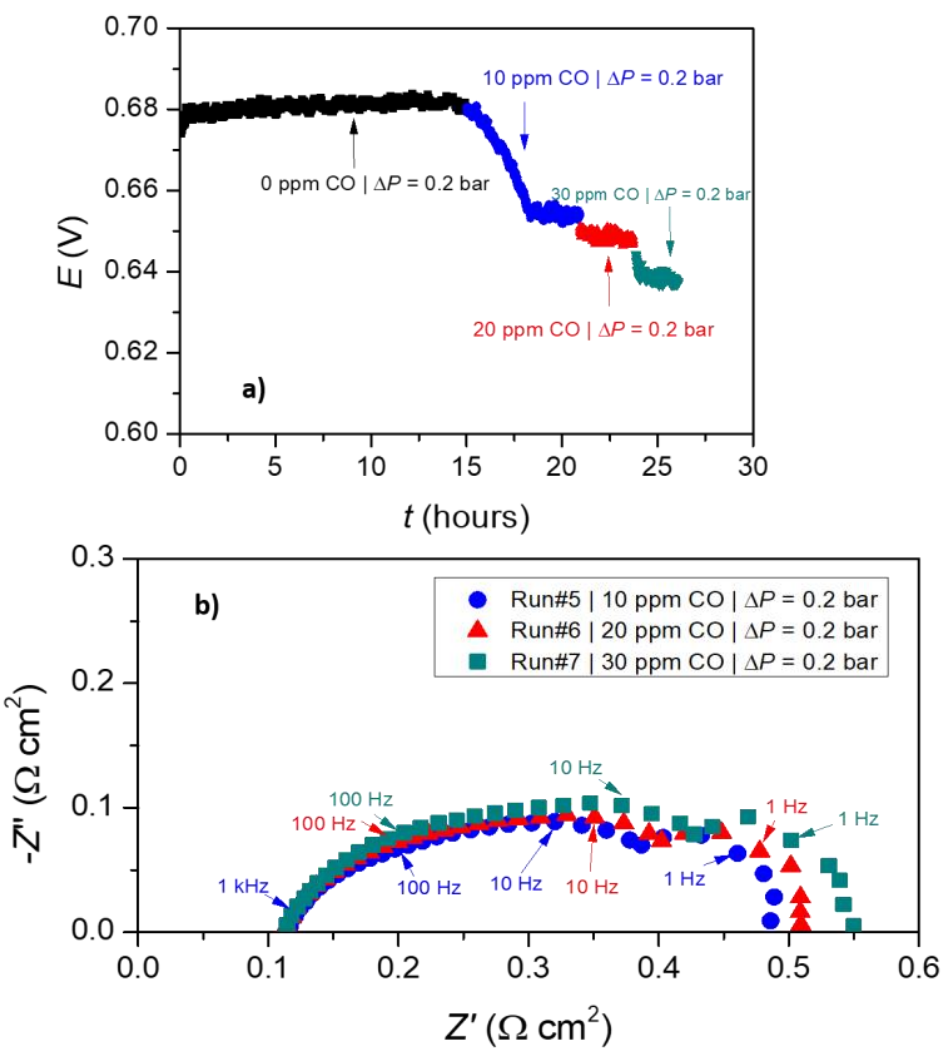

Figure 5. Effect of different $\mathrm{CO}$ concentrations at $500 \mathrm{~mA} \mathrm{~cm}{ }^{-2}$ on a) chronopotentiometry and on b) EIS in MEA\#1. 
The work of Dhar [42] reported that the apparent activation energy for the HOR increases with the $\mathrm{CO}$ concentration thus leading to higher anode polarizations. Oetjen [43] studied the effect of different $\mathrm{CO}$ concentrations ( 25 to $250 \mathrm{ppm}$ of $\mathrm{CO}$ ) on the performance a PEMFC at $80^{\circ} \mathrm{C}$. These authors concluded that feeding a cell with hydrogen with increasing $\mathrm{CO}$ contents causes a more negative slope on the polarization curve compared to that measured with pure hydrogen; this effect was more noticeable for higher current densities (> $300 \mathrm{~mA} \mathrm{~cm}$ ). Similar results were already reported by other authors. $[44,45]$.

The potential needed to oxidize hydrogen (potential range of 0 to $0.2 \mathrm{~V}$ ) is inferior to that needed to oxidize $\mathrm{CO}$ (a minimum of $350 \mathrm{mV}$ on $\mathrm{Pt} / \mathrm{Ru}$ ) [46,47]; the latter occupies the active sites following a Tempkin adsorption isotherm behaviour. If the temperature is kept constant, the CO coverage increases with its concentration in the feed, progressively blocking the active sites for the HOR resulting in lower performances [42].

\subsection{External air bleeding}

Figure 6 a depicts the cell potential behaviour before and after introducing $10 \mathrm{ppm}$ of $\mathrm{CO}$ together with gradually higher concentrations of air $(0.5 \%, 1 \%$ and $1.5 \%)$ in the fuel stream. $0.5 \%$ of air is enough to cause significant gains in the performance ( $c a .45 \%$ ) while $1.5 \%$ of air in the anode suffices to mitigate the CO poisoning - Run \#10. Figure $6 \mathrm{~b}$ shows the EIS spectra for Runs \#2, \#3 and \#10. Runs $\# 2$ and \#10 displayed approximately the same anodic charge transfer resistance $R_{\mathrm{a}} \approx 68 \mathrm{~m} \Omega \mathrm{cm}^{2}$ and the same series resistance $R_{\mathrm{m}} \approx 217 \pm 4 \mathrm{~m} \Omega \mathrm{cm}^{2}$; the fuel feed of Run \#10 contains $1.5 \%$ of air (ca. $0.32 \%$ of oxygen), $10 \mathrm{ppm}$ of $\mathrm{CO}$ and the balance of hydrogen, this last from air.
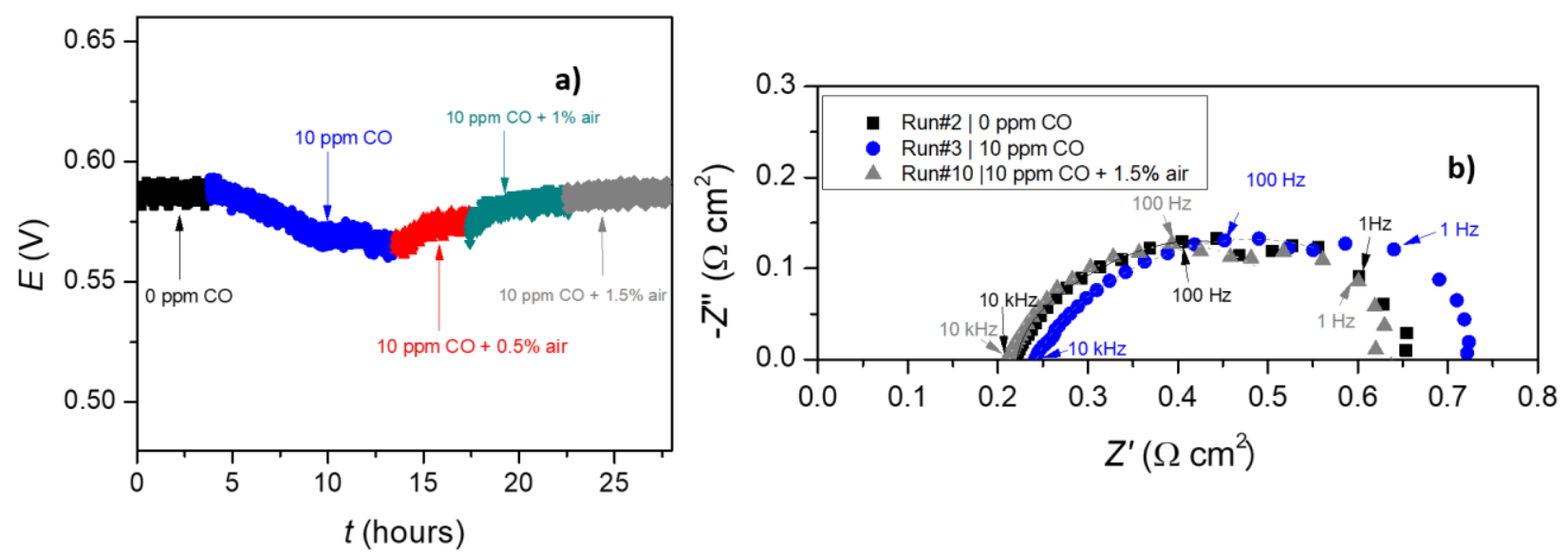

Figure 6. Effect of external bleeding at $500 \mathrm{~mA} \mathrm{~cm}^{-2}$ on a) chronopotentiometry and b) on EIS in MEA\#1.

The effect of external air bleeding was also assessed using MEA\#2. For this MEA, $1 \%$ of air was enough to fully recover the reference potential, $c f$. Run\#2 and \#9 in Figure 7a. Impedance spectra for Runs \#2, \#3 and \#9 are depicted in Figure 7b; spectra of Runs \#2 and \#9 overlap, confirming that the recovery from the $\mathrm{CO}$ poisoning was complete, in agreement with the characteristic curve results. Moreover, ohmic resistance increases when CO is added to the feed (Run \#3) and returns to the reference 
value when external bleeding is provided (Run \#9): $R_{\mathrm{m}}$ is ca. $125.4 \mathrm{~m} \Omega \mathrm{cm}^{2}$ for Run \#3 and $R_{\mathrm{m}}$ of 107 $\pm 2 \mathrm{~m} \Omega \mathrm{cm}^{2}$ for Run \#2 and \#9).

Several works in the literature report that the addition of a fraction of air to a CO contaminated hydrogen stream allows the recovery of the fuel cell performance as if it was operating with pure hydrogen [48-53]. Higher CO concentrations typically require higher levels of air bleeding; for example, anode air bleeding of $15 \%$ ( $c a .3 \%$ of oxygen) is not enough to fully recover the performance of a cell fed with a 53 ppm CO-contaminated hydrogen stream [54]. However, excessive air bleeding (>15\%) is dangerous and leads to the fast membrane ageing and to the decrease of the output power since a significant amount of fuel oxidizes to water at the anode side. Nevertheless, the work by Wilson and his co-workers [55] is one of the few to report the effect of external air bleeding for mitigating $\mathrm{CO}$ poisoning present at low concentrations. These authors reported the use of an external bleeding stream of air ( $2 \%)$ for fully recover the performance of a PEMFC fed with hydrogen contaminated with $5 \mathrm{ppm}$ and $20 \mathrm{ppm}$ of $\mathrm{CO}$; the anode was loaded with $0.14 \mathrm{mg} \mathrm{cm}^{-2}$ of PtRu. A similar work comprehended the use of an external bleeding of $6.7 \%$ (air) for a recovery ratio of $80 \%$ with a 10 ppm CO-contaminated hydrogen stream while using a $0.45 \mathrm{mg} \mathrm{cm}^{-2} \mathrm{Pt}-\mathrm{Ru}$ anode [54].

The oxygen reaction with the adsorbed $\mathrm{CO}$ on the catalyst surface produces $\mathrm{CO}_{2}$. As soon as the $\mathrm{CO}$ is oxidized and removed, the catalyst sites become available for the HOR. Here, it is reported that 1 $-1.5 \%$ of anode air bleed is sufficient to completely recover the performance of a $10 \mathrm{ppm} \mathrm{CO}$ contaminated fuel stream under typical operating conditions, i.e. m-CHP systems. To safely supply oxygen (or air) into the anode, its concentration should be kept always below the limiting oxygen concentration, which for 1 bar and room temperature is ca. $5 \%$ of oxygen [56]. Furthermore, such oxygen content at the anode did not impact the open circuit potential of the cell, thus it does not contribute for lowering the PEMFC performance.
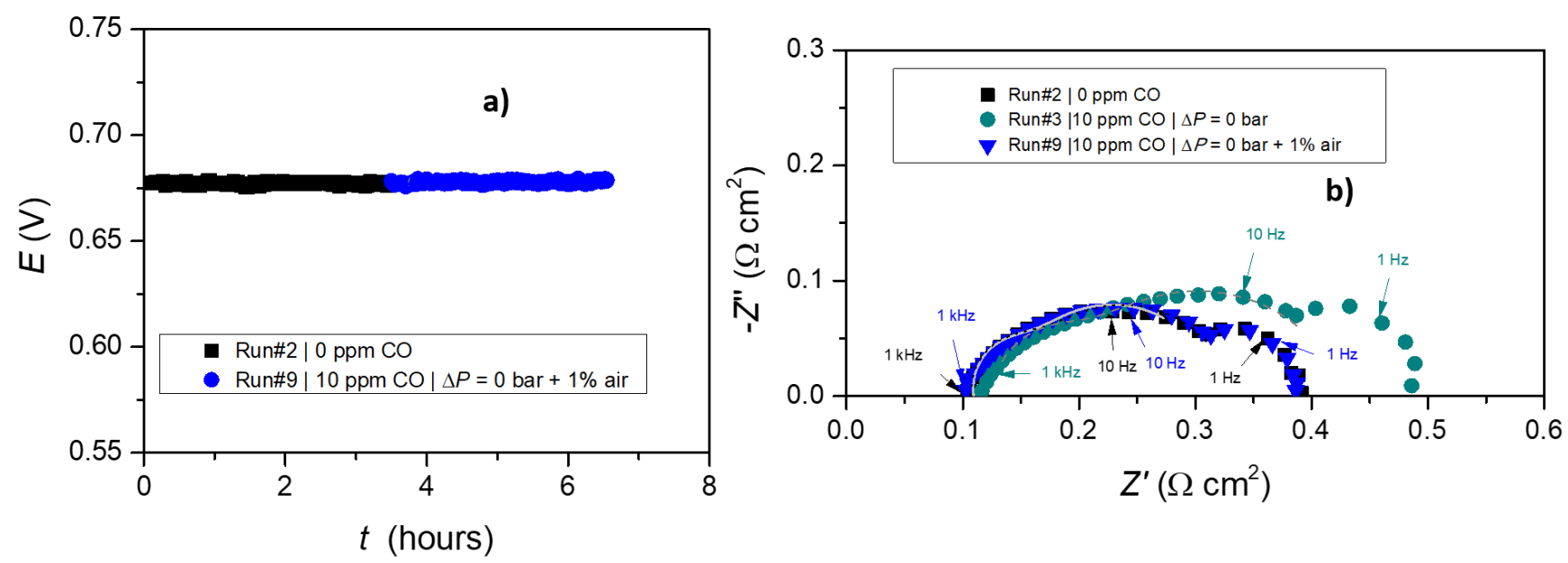

Figure 7. Effect of external air bleeding at $500 \mathrm{~mA} \mathrm{~cm}^{-2}$ on a) chronopotentiometry and on b) EIS in MEA\#2.

\subsection{Cell electrochemical stability upon implementation of bleeding strategies}

Figure $8 \mathrm{a}$ and $\mathrm{b}$ compare long-term chronopotentiometries of Run \#5 and Runs \#9 and \#10 with internal and external air bleeding, respectively, for MEA\#1 and MEA\#2. After reaching the steady-state 
potential at a current density of $500 \mathrm{~mA} \cdot \mathrm{cm}^{-2}$, the potential loss history was recorded for assessing the long-term stability. A potential loss rate of $1.58 \cdot 10^{-4} \mathrm{~V} \mathrm{~h}^{-1}$ is observed for an internal bleeding of 200 mbar of cathode over-pressure - Run \#5 in MEA\#1; on the other hand, after $c a .80 \mathrm{~h}$ of operation, MEA\#2 displays a potential loss rate of $9.45 \cdot 10^{-5} \mathrm{~V} \mathrm{~h}^{-1}$ under the same operating conditions. After $c a .8$ $\mathrm{h}$ of operation the performance loss of MEA\#1 under external bleeding is negligible (loss rate of $c a$. $4.30 \cdot 10^{-6} \mathrm{~V} \mathrm{~h}^{-1}$ ) - Run \#10, while MEA\#2 displays a potential loss rate of $8.04 \cdot 10^{-5} \mathrm{~V} \mathrm{~h}^{-1}-$ Run \#9. At reference conditions, for a $\mathrm{CO}$ free hydrogen feeding, the observed potential loss rate was $9.43 \cdot 10^{-7} \mathrm{~V}$ $\mathrm{h}^{-1}$ for MEA\#1 and 9.00 $10^{-6} \mathrm{~V} \mathrm{~h}^{-1}$ for MEA\#2. These values are quite similar to the ones obtained for the external bleeding experiments, showing that this method is not only sufficient to recover the performance of the cell but also causes less cell potential decay than internal bleeding; nonetheless, some authors have reported a detrimental effect in long-term performance when using external air bleeding due to $\mathrm{H}_{2} \mathrm{O}_{2}$ formation [16]. However, the results of demonstrate that MEA\#1, that uses a thicker membrane, displays a better long-term stability even at higher air bleed concentrations than MEA\#2 $1.5 \%$ air bleed in MEA\#1 vs. $1 \%$ of air in MEA\#2.
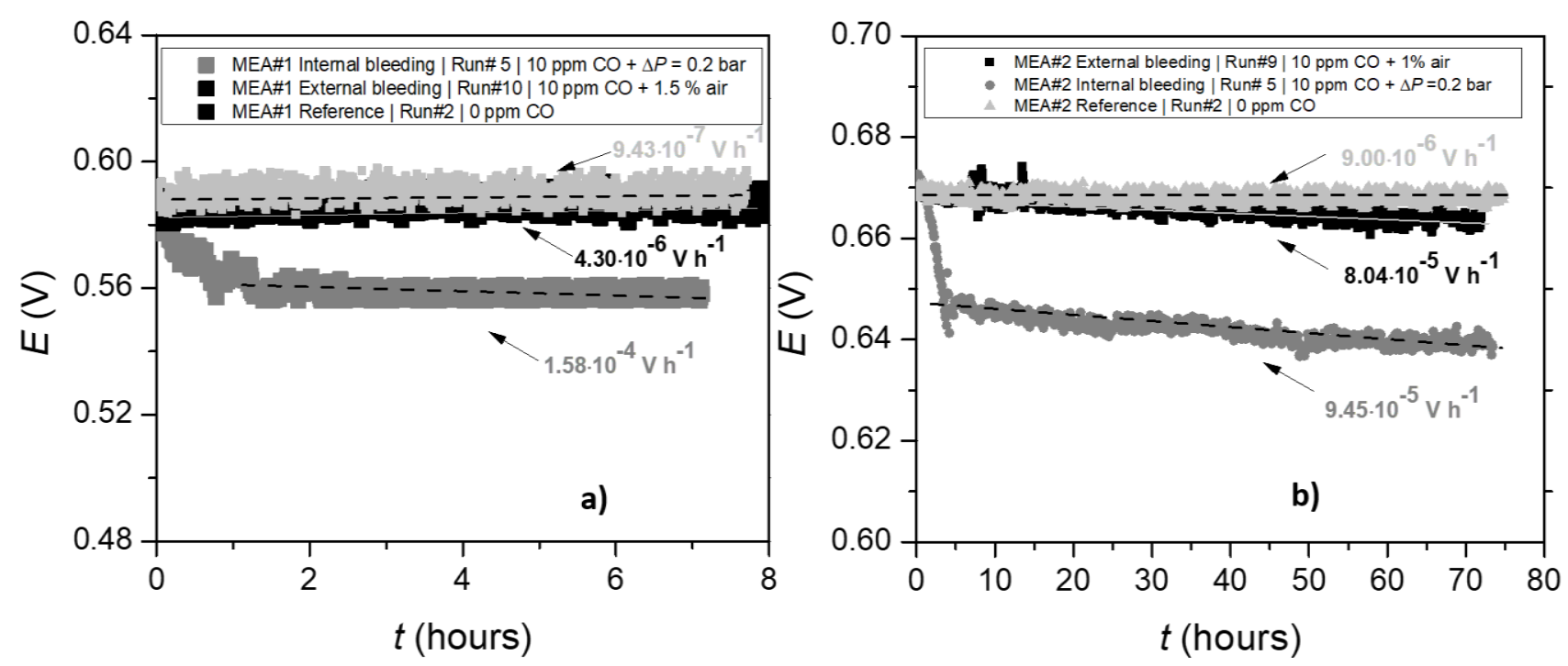

Figure 8. Long-term chronopotentiometry of two types of air bleeding at $500 \mathrm{~mA} \mathrm{~cm}^{-2}$ in a) MEA\#1 and b) MEA\#2.

Cyclic voltammetry was performed to assess the impact of CO contamination over both anode and cathode ECSA after a complete set of experiments (Runs\# 3 to 9) with MEA\#2. Figure 9a and b depict the BoL CV, and the end of life (EoL) CV for the anode and cathode of MEA\#2, respectively. The CVs present distinct shapes due to the different catalysts used in each electrode. The peak areas reflect the number of $\mathrm{Pt}$ active sites to hydrogen adsorption/desorption. The anode CVs display solely one peak typical of Pt-Ru catalysts [57]. On the other hand, the cathode displays two peaks at the anodic currents region ( $i>0$ ) accounting for the $\mathrm{H}$ desorption on $\mathrm{Pt}(111)$ at $\sim 110 \mathrm{mV}$ and $\mathrm{Pt}(100)$ at $\sim 215$ $\mathrm{mV}$ [58]. The reduction process is electrochemically reversible since the difference between the anodic and cathodic peak potentials is less than $59 \mathrm{mV}$. After performing all tests involving CO coverage, the electrochemically active surface area seems to be kept intact with no signs of loss on catalytic activity, 
Figure 9c. This result confirms the great stability of Pt-Ru alloy towards $\mathrm{CO}$ contaminated hydrogen streams [59]. Moreover, Wagner and Schulze [60] confirmed by EIS analysis the excellent properties of $\mathrm{Pt}-\mathrm{Ru} / \mathrm{C}$ anodes as CO-tolerant electrocatalysts for the HOR; not only do they provide less anodic charge transfer resistance but also generate less mass transfer resistance compared to $\mathrm{Pt} / \mathrm{C}$ based anodes. However, there is an evident loss of active surface area of $\mathrm{Pt}$ at the cathode, nearly $16 \%$, due to the typical catalyst layer degradation that comprehends Pt dissolution/sintering, carbon corrosion and ionomer dissolution [61].
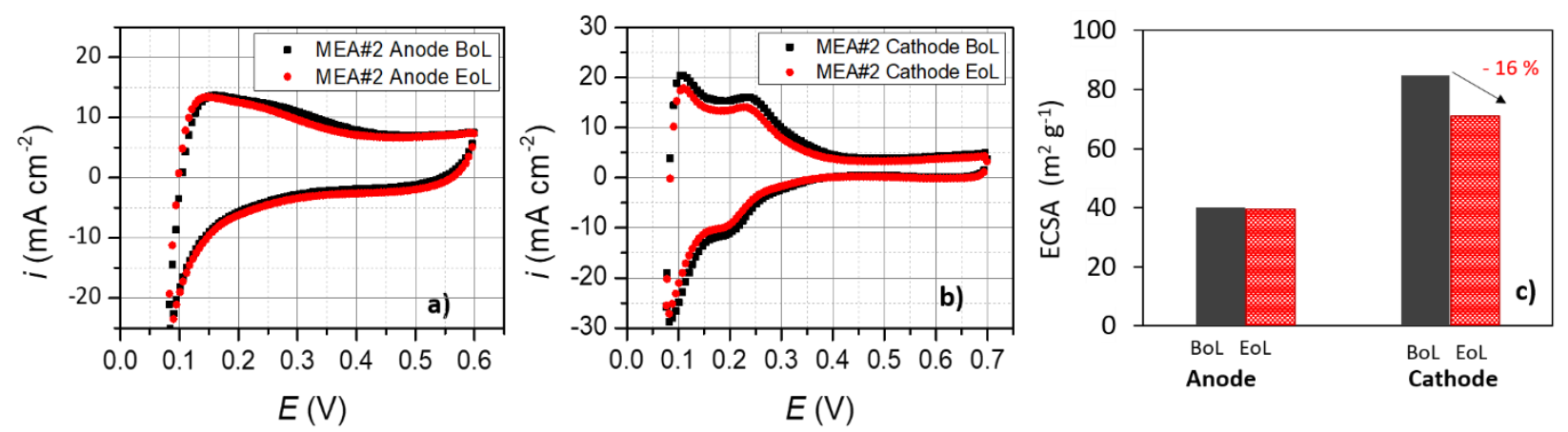

Figure 9. Cyclic voltammograms at beginning of life (BoL) and end of life (EoL) of the a) anode and b) cathode of MEA\#2; scan rate: $50 \mathrm{mV} \cdot \mathrm{s}^{-1}$; $\mathrm{RH}$ : $50 \%$; Stoic.: $1.5 / 2\left(\mathrm{H}_{2} / \mathrm{O}_{2}\right)$ at $\left.100 \mathrm{~mL} \cdot \mathrm{min}^{-1}\right)$.

\section{CONCLUSIONS}

In the present study, the performance of PEMFCs was evaluated while feeding $\mathrm{H}_{2}$ and $\mathrm{CO}$ (10 $\mathrm{ppm}$ ) to a Pt-Ru based anode and compared with the performance with pure hydrogen at $70{ }^{\circ} \mathrm{C}$. Oxygen concentrations were tuned and applied to the anode - by means of internal air or external air bleeding to assess the minimum concentration to mitigate $\mathrm{CO}$ poisoning. Simultaneously, the long-term stability of the cells was monitored to ascribe the potential decay with each air bleeding strategy.

The potential drop caused by feeding $\mathrm{H}_{2}$ contaminated with $10 \mathrm{ppm}$ of $\mathrm{CO}$ was $3 \%$ at 500 $\mathrm{mA} \cdot \mathrm{cm}^{-2}$ for the fuel cells equipped with Nafion HP membrane and a Nafion 212 membrane; nonetheless, the dynamic response to the addition of $10 \mathrm{ppm}$ of $\mathrm{CO}$ was slow, reaching the new steady state performance after $c a .5 \mathrm{~h}$. The air feed over-pressure of 0.2 bar at the cathode allowed the reactivation of the poisoned catalyst and a cell potential recovery of over $30 \%$ in both MEAs. The success of internal bleeding towards $\mathrm{CO}$ oxidation along with the stability was found to depend on the mechanical strength of each membrane that equipped the MEAs. Thinner but reinforced and stabilized Nafion HP membrane displayed lower performance recovery but higher stability during mid-term diagnosis, in contrast to the non-reinforced and thicker Nafion 212 membrane.

Performing external air bleeding proved to be the most effective approach. In fact, adding an air bleed of $1 \%$ and $1.5 \%$ in the fuel stream for both MEAs promoted full CO oxidation and thus nearly $100 \%$ recovery of cell performance (comparing to neat hydrogen). Accordingly, up to $1.5 \%$ of air in the anode side showed to be harmless for long-term operation. This strategy is then recommendable for stationary applications, namely for residential power generation, whenever the feeding hydrogen contains up to $c a$. $10 \mathrm{ppm}$. 


\section{ACKNOWLEDGEMENTS}

The authors acknowledge the financial support from the project UID/EQU/00511/2019 - Laboratory for Process Engineering, Environment, Biotechnology and Energy - LEPABE funded by national funds through FCT/MCTES (PIDDAC) and PEMFC-SUDOE - $\mathrm{n}^{\circ}$ SOE1/P1/E0293 funded by FEDER funds through COMPETE2020 - Programa Operacional Competitividade e Internacionalização (POCI) and Programa Operacional Regional do Norte (NORTE2020) and by national funds (PIDDAC) through FCT/MCTES.

\section{References}

1. J. Tjønnås, F. Zenith, I.J. Halvorsen, M. Klages, J. Scholta, IFAC-PapersOnLine, 49 (2016) 302-307.

2. C.A. Rice, P. Urchaga, A.O. Pistono, B.W. McFerrin, B.T. McComb, J. Hu, J. Electrochem. Soc., 162 (2015) F1175-F1180.

3. S. Foresti, G. Manzolini, S. Escribano, Int. J. Hydrogen Energy, 42 (2017) 25334-25350.

4. T.J. Park, S.M.; O'Brien, Effects of Several Trace Contaminants on Fuel Cell Performance, (1979).

5. N. Hayter, P R; Mitchell, P; Dams, R A.J.; Dudfield, C; Gladding, The Effect of Contaminants in the Fuel and Air Streams on the Performance of a Solid Polymer Fuel Cell, (1997).

6. P.E. Dodds, I. Staffell, A.D. Hawkes, F. Li, P. Grünewald, W. McDowall, P. Ekins, Int. J. Hydrogen Energy, 40 (2015) 2065-2083.

7. I. Staffell, Appl. Energy, 147 (2015) 373-385.

8. R.A. Lemons, J. Power Sources, 29 (1990) 251-264.

9. H. Igarashi, T. Fujino, M. Watanabe, J. Electroanal. Chem., 391 (1995) 119-123.

10. X. Cheng, Z. Shi, N. Glass, L. Zhang, J. Zhang, D. Song, Z.S. Liu, H. Wang, J. Shen, J. Power Sources, 165 (2007) 739-756.

11. Z. Qi, C. He, A. Kaufman, J. Power Sources, 111 (2002) 239-247.

12. R.J. Bellows, E.M. Soos, R.P. Reynolds, Electrochem. Solid-State Lett., 1 (1999) 69.

13. L.P.L. Carrette, K.A. Friedrich, M. Huber, U. Stimming, Phys. Chem. Chem. Phys., (2001).

14. C.-C. Chung, C.-H. Chen, D.-Z. Weng, Appl. Therm. Eng., 29 (2009) 2518-2526.

15. R. Bashyam, P. He, S. Wessel, S. Knights, ECS Trans., (2011).

16. S. Knights, R. Bashyam, P. He, M. Lauritzen, C. Startek, V. Colbow, T. Cheng, J. Kolodziej, S. Wessel, ECS Trans., 41 (2011) 39-53.

17. M.J. Lee, J.S. Kang, Y.S. Kang, D.Y. Chung, H. Shin, C.Y. Ahn, S. Park, M.J. Kim, S. Kim, K.S. Lee, Y.E. Sung, ACS Catal., 6 (2016) 2398-2407.

18. S. Alayoglu, A.U. Nilekar, M. Mavrikakis, B. Eichhorn, Nat. Mater., 7 (2008) 333-338.

19. A.H. Thomason, T.R. Lalk, A.J. Appleby, J. Power Sources (2004).

20. Y. Kurihara, T. Mabuchi, T. Tokumasu, J. Electrochem. Soc. (2017).

21. T. Kawakami, I. Shigemoto, N. Matubayasi, J. Chem. Phys. (2012).

22. A.T. Haug, R.E. White, J. Electrochem. Soc. (2000).

23. P. Gode, G. Lindbergh, G. Sundholm, J. Electroanal. Chem. (2002).

24. K. Lee, A. Ishihara, S. Mitsushima, N. Kamiya, K. Ota, J. Electrochem. Soc. (2004).

25. V.A. Sethuraman, S. Khan, J.S. Jur, A.T. Haug, J.W. Weidner, Electrochim. Acta (2009).

26. S.S. Kocha, J.D. Yang, J.S. Yi, AIChE J., 52 (2006).

27. J. Zhang, T. Thampan, R. Datta, J. Electrochem. Soc. (2002).

28. M. Murthy, M. Esayian, A. Hobson, S. Mackenzie, W. Lee, J.W. Van Zee, M. Murthy,a, J.W. Van Zee, J. Electrochem. Soc. (2001).

29. Y. V. Pleskov, Y.E. Evstefeeva, M.D. Krotova, V. V. Elkin, A.M. Baranov, A.P. Dement'Ev, Diam. Relat. Mater., 8 (1999) 64-72.

30. X.-Z. Yuan, S. Zhang, H. Wang, J. Wu, J.C. Sun, R. Hiesgen, K.A. Friedrich, M. Schulze, A. 
Haug, J. Power Sources, 195 (2010) 7594-7599.

31. L. Yu, F. Lin, L. Xu, J. Xi, RSC Adv., 7 (2017) 31164-31172.

32. DuPont Fuel Cells, DuPont ${ }^{\mathrm{TM}}$ Nafion ${ }^{\circledR}$ PFSA Membranes NR-211 and NR-212, (2008).

33. DuPont Fuel Cells, (2010).

34. S. Slade, S.A. Campbell, T.R. Ralph, F.C. Walsh, J. Electrochem. Soc., 149 (2002) A1556.

35. X.-Z. Yuan, S. Zhang, H. Wang, J. Wu, J.C. Sun, R. Hiesgen, K.A. Friedrich, M. Schulze, A. Haug, J. Power Sources, 195 (2010) 7594-7599.

36. M.N. Tsampas, A. Pikos, S. Brosda, A. Katsaounis, C.G. Vayenas, Electrochim. Acta, 51 (2006) 2743-2755.

37. W. Wang, J. Power Sources, 191 (2009) 400-406.

38. K.M. Nouel, P.S. Fedkiw, Electrochim. Acta, 43 (1998) 2381-2387.

39. F. Liu, B. Yi, D. Xing, J. Yu, H. Zhang, J. Memb. Sci., 212 (2003) 213-223.

40. J. Shim, H.Y. Ha, S.-A. Hong, I.-H. Oh, J. Power Sources, 109 (2002) 412-417.

41. H.-L. Lin, T.L. Yu, L.-N. Huang, L.-C. Chen, K.-S. Shen, G.-B. Jung, J. Power Sources, 150 (2005) 11-19.

42. H.P. Dhar, L.G. Christner, A.K. Kush, H.C. Maru, J. Electrochem. Soc. , 133 (1986) 15741582.

43. U. Oetjen, H.-F., Schmidt, V.M , Stimming, J. Electrochem. Soc., 143 (1996) 3838.

44. V.M. Schmidt, R. Ianniello, H.-F. Oetjen, H. Reger, U. Stinuning, F. Trila, ECS Proc. Vol. , 1995-23 (1995) 1-11.

45. Y. Si, R. Jiang, J.-C. Lin, H.R. Kunz, J.M. Fenton, J. Electrochem. Soc., 151 (2004) A1820A1824.

46. Y. Takasu, T. Kawaguchi, W. Sugimoto, Y. Murakami, Electrochim. Acta, 48 (2003) 38613868.s

47. T. Gu, W.-K. Lee, J.W. Van Zee, M. Murthy, J. Electrochem. Soc., 151 (2004) A2100-A2105.

48. L.Y. Sung, B.J. Hwang, K.L. Hsueh, F.H. Tsau, J. Power Sources, 195 (2010) 1630-1639.

49. T. Tingelöf, L. Hedström, N. Holmström, P. Alvfors, G. Lindbergh, Int. J. Hydrogen Energy, 33 (2008) 2064-2072.

50. L.Y. Sung, B.J. Hwang, K.L. Hsueh, W.N. Su, C.C. Yang, J. Power Sources, 242 (2013) 264272.

51. F.A. Uribe, J.A. Valerio, F.H. Garzon, T.A. Zawodzinski, Electrochem. Solid-State Lett., 7 (2004) A376-A379.

52. R.C. Urian, A.F. Gullá, S. Mukerjee, J. Electroanal. Chem., 554-555 (2003) 307-324.

53. T. Morawietz, M. Handl, C. Oldani, K.A. Friedrich, R. Hiesgen, ACS Appl. Mater. Interfaces, 40 (2016) 27044-27054.

54. X. Cheng, Z. Shi, N. Glass, L. Zhang, J. Zhang, D. Song, Z.-S. Liu, H. Wang, J. Shen, J. Power Sources, 165 (2007) 739-756.

55. S.F.. Wilson, M.S., Derouin, C.R., Valerio, J.A., and Gottesfeld, Conf. 28. Intersoc. Energy Convers. Eng. Conf. Atlanta, GA (United States), 8-13 Aug 1993, (1193).

56. I.A. Zlochower, G.M. Green, J. Loss Prev. Process Ind., 22 (2009) 499-505.

57. S.J. Yoo, T.Y. Jeon, K.S. Kim, T.H. Lim, Y.E. Sung, Phys. Chem. Chem. Phys., 46 (2010) $15240-15246$.

58. W. Sheng, Z. Zhuang, M. Gao, J. Zheng, J.G. Chen, Y. Yan, Nat. Commun., 6 (2015) 5848.

59. H.-F. Oetjen, J. Electrochem. Soc. (1996).

60. N. Wagner, M. Schulze, Electrochim. Acta, 48 (2003) 3899-3907.

61. X. Yu, S. Ye, J. Power Sources, 172 (2007) 145-154.

(C) 2020 The Authors. Published by ESG (www.electrochemsci.org). This article is an open access article distributed under the terms and conditions of the Creative Commons Attribution license (http://creativecommons.org/licenses/by/4.0/). 